\title{
PENGEMBANGAN MODEL PEMBELAJARAN SERVIS BAWAH PERMAINAN BOLA VOLI
}

\author{
Marsiyem $^{1)}$, Destriana ${ }^{2)}$,dan Reza Resah Pratama ${ }^{3)}$ \\ ${ }^{1,2,3}$ Pendidikan Jasmani dan Kesehatan, Fakultas Keguruan dan Ilmu Pendidikan, Universitas Sriwijaya \\ 1,2,3 Jalan Palembang-Prabumulih, Km 32 Inderalaya, kabupaten Ogan Ilir, 30662 \\ E-mail: marsiyem@fkipunsri.ac.id, destriana@fkip.unsri.ac.id ${ }^{1)}$, rezarpunsri@gmail.com ${ }^{3}$
}

\begin{abstract}
ABSTRAK
Penelitian ini bertujuan untuk mengembangkan model pembelajaran servis bawah permainan bola voli untuk siswa SMP kelas VII dengan dimaksudkan untuk meningkatkan hasil belajar siswa. Pengembangan model pembelajaran servis bawah dilakukan pada Sekolah Menengah Pertama Negeri 1 Palembang dengan menggunakan metode penelitian $R \& D$ yang dikembangkan oleh Sugiono. Tahapan penelitian adalah analisis kebutuhan, pembuatan draf produk, validasi ahli, ujicoba skala kecil, revisi, ujicoba skala besar, revisi tahap 2, serta ujiefektifitas produk. Teknik analisis data kuantitatif deskriptif. Hasil penelitian ini pada validasi ahli tahap 2 di dapatkan penilaian sebesar $80 \%$ dari ahli PJOK dan 81,67\% dari ahli permainan bola voli maka produk dikatakatan "Layak". Ujicoba skala besar dilakukan pada 3 kelas dengan jumlah responden sebanyak 72 siswa didapatkan hasil yaitu, 90,74\% siswa berada pada kategori baik, sehingga produk ini dinyatakan "Layak". Temuan pada penelitian ini adalah dihasilkannya model pembelajaran servis bawah permainan bola voli yang digunakan siswa SMP kelas VII berupa buku panduan.
\end{abstract}

Kata kunci: Model Pembelajaran, Servis Bawah, Permainan Bola Voli

\section{PENDAHULUAN}

Pelaksanaan pendidikan dalam pembelajaran, khususnya dalam cabang pendidikan olahraga maupun dalam pendidikan jasmani baik dalam satuan pendidikan di tingkat sekolah dianggap masih memerlukan perbaikan-perbaikan guna menunjang tercapainya tujuan pembelajaran.

Menurut Rahayu (2013) Pendidikan jasmani, olahraga, dan kesehatan adalah proses pendidikan yang memanfaatkan aktivitas fisik untuk memperoleh kemampuan individu, baik dalam hal fisik, mental serta emosional. Ada beberapa alasan sehingga dinilai memerlukan pengembangan pada mata pelajaran permainan bola voli, diantaranya kurangnya variasi guru terhadap siswa dalam proses belajar mengajar dan kreatifitas pendidik yang terbatas dalam kegiatan pembelajaran.

Teknik dasar merupakan suatu gerak dasar yang harus dimiliki oleh seorang pemain bolavoli baik dalam gerakan kaki dan juga gerakan tubuhnya. Teknik servis merupakan hal utama dalam permainan bola voli, karena berlangsungnya permainan harus didahulukan dengan melakukan servis. Teknik servis bawah permainan bola voli memerlukan beberapa aspek fisik maupun psikologi, antara lain kekuatan otot lengan, daya ledak otot, dan koordinasi. Servis bawah juga memerlukan konsentrasi yang tinggi pada setiap unsur gerakannya, sehingga perlu adanya pengembangan dalam proses pembelajaran yang tepat dengan mempertimbangkan faktor tersebut agar siswa dengan mudah menguasai dan terampil dalam melakukan teknik servis pada permainan bola voli.

Hasil penelitian yang dilakukan Aditama, Z.,\& Hidayat, T (2014) diperoleh data dengan peningkatan hasil yang signifikan untuk pembelajaran ketepatan service bawah bolavoli sebesar 63,93\% melalui model penerapan model pembelajaran STAD (student teamsachievement division) serta penelitian yang dilakukan Alif, E., Heny, S., \& Cahyo, Y. (2012) dari hasil penelitian yang dilakukan pada siswa sekolah dasar terdapat rata-rata uji coba lebih dari $80 \%$ siswa dapat mempraktikkan dan memahami dengan baik sehingga baik dari uji coba kelompok kecil maupun uji coba lapangan, sehingga permainan bola voli mini berlapis sebagai produk yang telah dihasilkan dapat digunakan sebagai alternatif penyampaian materi pembelajaran bola voli.

Penelitian ini dimaksudkan untuk mengambil bidang yang belum diteliti oleh peneliti sebelumnya. Penelitian ini dimaksudkan untuk pengembangankan model pembelajaran servis bawah pada Sekolah Menengah Pertama. Dengan adanya variasi model pembelajaran bola voli sehingga dapat meningkatkan pembelajaran servis bawah menjadi lebih efektif dan efisien.

\section{RUANG LINGKUP}

Masalah penelitian ini dibatasi pada bagaimana mengembangkan model pembelajaran servis bawah permainan bola voli untuk siswa SMP kelas VII. Dengan permasalahan kurang bervariasinya bahan ajar guru Pendidikan Jasmani. Penelitian menghasilkan model 
pembelajaran yang dapat meningkatkan hasil belajar pada ranah pengetahuan, sikap dan keterampilan.

\section{BAHAN DAN METODE}

Belajar mempunyai makna sebagai proses perubahan tingkah laku sebagai akibat adanya interaksi antara individu dengan lingkunganya. Tingkah laku itu mencakup aspek pengetahuan, keterampilan, dan sikap (Husdarta, 2013). Menurut Agus Suprijono (2010) Model pembelajaran ialah pola yang digunakan sebagai pedoman dalam merencanakan pembelajaran dikelas maupun tutorial. Model Pembelajaran adalah suatu kerangka konseptual yang berisi prosedur sistematik dan mengorganisasikan pengalaman belajar siswa untuk mencapai tujuan belajar tertentu yang befungsi sebagai pedoman bagi guru dalam proes belajar mengajar (Syaiful Sagala, 2010).

Servis bawah adalah servis yang paling sederhana, dan banyak dilakukan oleh pemain pemula. Ciri hasil pukulan servis adalah melambung, sehingga bagi pemain yang sudah memiliki keterampilan tinggi, menerima bola dari servis ini sangat mudah (Subroto dan Yudiana, 2010). Service tangan bawah adalah usaha untuk memulai pertandingan dan mengarahkan bola ke arah lapangan lawan yang dilakukan oleh pemain yang berada didaerah service, pemain memukul bola dengan satu tangan dibawah pinggang atau kira-kira setinggi pinggang (M.E. Winarno dkk, 2013).

Metode Penelitian yang digunakan adalah research and development (R\&D). Sugiyono (2013) berpendapat metode penelitian dan pengembangan adalah metode penelitian yang digunakan untuk menghasilkan produk tertentu, dan menguji keefektifan produk tersebut. Langkah-langkah pengembangan terdiri dari sepuluh langkah dimodifikasi menjadi 8 langkah.

Gambar 1. Di ibawah ini menjelaskan prosedur penelitian servis bawah sebagai berikut:

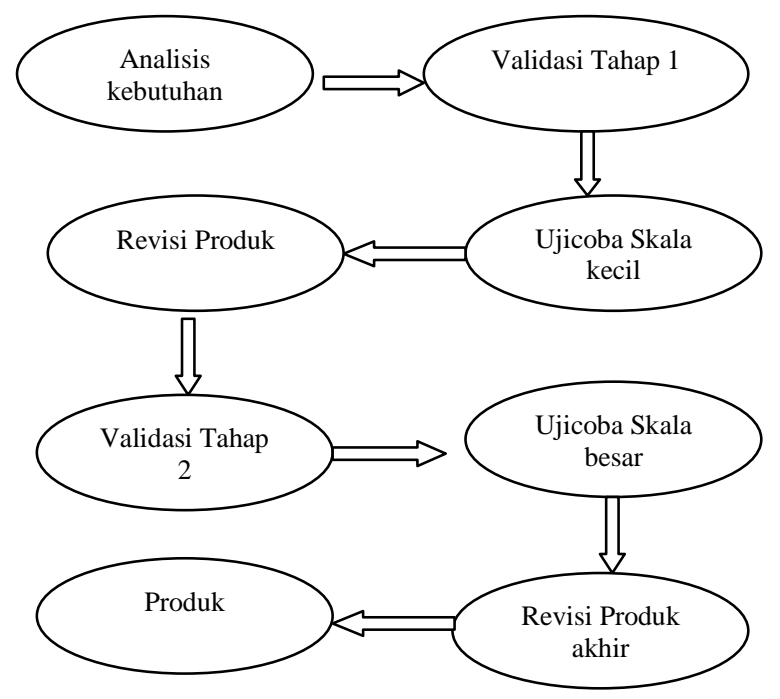

Gambar 1. Prosedur Penelitian Pengembangan Servis bawah
Teknik analisis data digunakan analisis data kuantitatif deskriptif. Penelitian pengembangan ini dilaksanankan di SMP N 1 Palembang Kelas VII semester 1 tahun ajaran 2018/2019. Instrumen yang digunakan berupa kuesinor serta lembar observasi.

\section{PEMBAHASAN}

Berikut ini adalah hasil dan pembahasan penelitian yang akan disajikan sebagai berikut:

\subsection{Hasil Pengembangan Model Pembelajaran Servis Bawah}

Pengembangan model pembelajaran servis bawah ini berupa buku panduan yang berisikan model pembelajaran servis bawah yang dapat digunakan oleh guru PJOK dalam pembelajaran permainan bola voli. Dalam keterampilan individu bola voli, seperti servis, adalah bagian kecil dari aspek analisis latihan keterampilan teknik dasar bola voli, terutama untuk kaum atlet pemula (Parisi, F., Raiola, G. 2014). Buku panduan model servis bawah ini berisikan beberapa materi sebagai berikut yaitu: sejarah permainan bola voli secara singkat, sarana dan prasarana dalam permainan bola, teknik servis bawah, serta model-model yang dikembangkan berupa langkah-langkah pembelajaran servis bawah. Berdasarkan teori model penelitian pengembangan Sugiyono (2013), jika diterapkan dalam pembelajaran ini yakni: (1) melakukan analisis kebutuhan yang akan dikembangkan yang didapat dari hasil mengumpulkan informasi, termasuk observasi lapangan dan kajian pustaka, (2) mengembangkan model pembelajaran bola voli berupa permainan voli persegi empat, (3)evaluasi dari ahli penjas dan ahli pembelajaran, serta uji coba skala kecil, kemudian dianalisis, (4) revisi produk pertama, revisi produk berdasarkan hasil dari evaluasi ahli dan uji coba skala kecil. Revisi ini digunakan untuk perbaikan terhadap produk yang dibuat oleh peneliti, (5) uji coba lapangan skala besar, (6) revisi produk akhir yang akan dilakukan berdasarkan hasil uji coba lapangan, (7) hasil akhir berupa pengembangan model servis bawah ini berupa buku panduan yang diperuntukan untuk guru PJOK, sehingga langsung dapat digunakan di lapangan.

\subsection{Analisis Kebutuhan Pengembangan Model Servis Bawah}

Langkah awal penelitian ini adalah analisis kebutuhan, langkah ini dilakukan untuk mengetahui permasalahan yang terjadi dilapangan yang berkaitan dengan model pengembangan servis bawah permainan bola voli. Pada saat disekolah dan pembelajran khususnya materi permainan bola voli, jumlah jam yang digunakan dalam pembelajaran PJOK adalah 3 JP yang 1 JP nya adalah 40 menit. Menurut hasil observasi pada SMP Negeri 1, saat pelaksanaan pembelajaran kurang maksimal dikarenakan kurangnya variasi pembelajaran guru PJOK serta model yang digunakan hanya satu sampai 2 model pembelajaran. Berdasarkan kenyataan ini maka akan dikembangakan model pembelajaran 
servis bawah dalam permainan bola voli yang dapat meningkatkan model pembelajaran maka diharapkan hasil pembelajaran siswa kelas VII khususnya materi servis bawah dapat meningkat menjadi lebih baik.

\section{Validasi Ahli Tahap Pertama Pengembangan} Model Pembelajaran Servis

Validasi dilakukan oleh ahli materi yaitu guru PJOK dan ahli permainan bola voli.

Tabel. 1 Penilaian Model Pembelajaran Servis Bawah oleh Ahli Tahap 1

\begin{tabular}{llcc}
\hline No & Validasi Ahli & $\begin{array}{c}\text { Persentase } \\
\text { skor }\end{array}$ & Kriteria \\
\hline 1 & Ahli Materi & $75 \%$ & Cukup Layak \\
2 & Ahli Bola Voli & $76,7 \%$ & Layak \\
& Rata-Rata & $75,85 \%$ & Layak \\
\hline
\end{tabular}

Skor hasil penilaian oleh kedua ahli jika dirataratakan menjadi $75,85 \%$ sehingga produk dikatakan "Layak"

\subsection{Ujicoba Skala Kecil Pengembangan Model \\ Pembelajaran Bola Voli}

Berdasarkan prosedur pengembangan maka pelaksanaan pada dilakukan uji coba skala kecil, pada siswa kelas 7.6 dengan jumlah responden 12 siswa dilakukan pada 3 ranah yaitu keterampilan, sikap dan pengetahuan.

Dengan hasil ujicoba yang dilakukan pada ranahketerampilan didapatkan 8 siswa $(66,7 \%)$ berada pada kategori baik. Pada ranah sikap didapatkan 10 siswa $(91,67 \%)$ berada pada kategori baik, serta pada ranah pengetahuan didapatkan 9 siswa (75\%) siswa berada pada kategori baik. Hasil dari ujicoba skala kecil maka produk ini sudah dikatakan layak digunkan, meskipun terdapat banyak revisi

\subsection{Revisi Produk Pengembangan Model \\ Pembelajaran Servis Bawah}

Tahapan ini adalah tahapan revisi produk pertama pengembangan model servis bawah dalam permainan bola voli. Pengembangan model servis bawah dalam permainan bola voli ini mempertimbangkan hasil dari validasi ahli, baik ahli permainan bola voli dan ahli pendidikan jasmani. Adapun saran yang diberikan dapat terlihat dari instrumen yang diberikan kepada para ahli tersebut. Adapun revisi produk berupa model pembelajaran servis bola voli, gerakan dalam model pengembangan gerak melempar bola 5 kali ke atas serta, model pembelajaran jarak 6 meter, selain mempertimbangkan saran dari validator revisi produk ini juga melihat hasil ujicoba skala.

Hasil uji coba skala kecil berada pada ketegori baik, walaupun ada beberapa siswa yang berada pada kategori cukup, item perbaikan terlihat dari instrumen penilaian baik pada keterampilan, sikap, maupun pengetahuan yang diberikan terhadap siswa. Melihat hasil validasi ahli dan ujicoba skala kecil maka produk dilakukan perbaikan sesuai dengan kekurangan, setelah perbaikan hal yang dilakukan adalah validasi kembali produk.

\subsection{Validasi Tahap Kedua Pengembangan Model Pembelajaran Servis Bawah}

Validasi tahap kedua dilakukan setelah revisi yang dilakukan dari hasil validasi dan ujicoba skala kecil. Hasil validasi ahli materi dan ahli bola voli dapat dilihat pada Tabel 2. di bawah ini

Tabel. 2 Penilaian Model Pembelajaran Servis Bawah oleh Ahli Tahap 2

\begin{tabular}{llcc}
\hline No & Validasi Ahli & $\begin{array}{c}\text { Persentase } \\
\text { skor }\end{array}$ & Kriteria \\
\hline 1 & Ahli Materi & $80 \%$ & Layak \\
2 & Ahli Bola Voli & $81,68 \%$ & Layak \\
& Rata-Rata & $80,84 \%$ & Layak \\
\hline
\end{tabular}

Skor hasil penilaian oleh kedua ahli jika dirataratakan menjadi $80,84 \%$ sehingga produk dikatakan "Layak", menurut Zhanneta Kozina, dkk (2018) Kebugaran fisik kemampuan koordinasi dan komponen teknik pemain bola voli menempati tempat khusus dalam meningkatkan performa, hasil penelitian tersebut selaras dengan hasil validasi ahli materi mengenai teknik servis bawah permainan bola voli.

Berdasarkan hasil perhitungan statistik tersebut maka dapat dinyatakan produk yang telah direvisi dapat disimpulkan produk yang dikembangkan layak digunakan untuk dilanjutkan ketahapan uji coba skala besar.

\subsection{Ujicoba Skala Besar Ujicoba Skala Besar Pengembangan Model Pembelajaran Servis Bawah}

Ujicoba skala besar dilakukan setelah validasi tahap ke-2. Ujicoba skala besar dilakukan untuk melihat sejauh mana model pembelajaran servis bawah permainan bola voli dapat digunakan dengan mengambil responden adalah sebagai tempat yang terkena pengemabangan model pembelajaran bola voli, sehingga dapat diketahui kekurangan serta kelebihannnya. Ujicoba di lakukan pada siswa kelas 7.1, 7.5, dan 7.8 SMP 1 Kota Palembang berjumlah 72 siswa. Berikut ini disajikan data hasil ujicoba skala besar: 


\subsubsection{Uji Coba Pada Kelas 7.1}

Uji efektifitas dilakukan pada kelas 7.1 dengan melihat hasil pembelajaran pada tiga ranah sebagai berikut:

\section{Tes Keterampilan}

Instrumen yang digunakan untuk melihat kualitas pembelajaran serta proses dalam melakukan gerakan keterampilan servis bawah permainan bola voli. tes keterampilan ini menggunakan observasi. Hasil presentase penilaian tes keterampilan proses servis bawah yang dilakukan melalui observasi keterampilan gerak siswa di didapatkan 8 siswa atau $33,34 \%$ berada pada kategori sangat baik, 14 siswa atau 58,33\% berada pada kategori baik, dan 2 siswa atau $8,33 \%$ berada pada kategori cukup. Hasil tes keterampilan yang didapat 91,67\% siswa lulus KBM. Hasil tersebut diperkuat dengan teori Schmidt mencoba menggambarkan definisi keterampilan bahwa: "Keterampilan merupakan kemampuan untuk membuat hasil akhir dengan kepastian yang maksimum dan pengeluaran energi dan waktu yang minimum." Produk yang dihasilkan dapat dilakukan dengan baik oleh setiap siswa sehingga pada saat melakukan gerakan teknik dasar servis bawah bola voli mudah dipahami dan dilakukan oleh siswa.

2. Tes sikap

Berdasarkan teori sikap adalah kesadaran individu yang menentukan perbuatan nyata dan perbuatanperbuatan yang akan terjadi, jadi merupakan suatu hal yang menentukan sikap sifat, hakikat baik perbuatan sekarang maupun perbuatan yang akan datang. Sikap dapat berkembang seiring dengan tingkat kematangan seseorang. Dalam kaitanya dengan pembelajaran permainan bola voli passing bahwa hasil presentase penelilaian observasi sikap servis bawah didapatkan 6 siswa atau $25 \%$ berada pada kategori sangat baik, 17 siswa atau 70,83\% berada pada kategori baik dan 1 siswa atau $4,17 \%$ berada pada kategori cukup, dari hasil observasi tersebut didapatkan $95,83 \%$ dinyatakn lulus KBM. Dengan demikin model pengembangan yang idlakukan memebrikan dapmapk yang baik bagi perkembangan sikap siswa dan layak dijadikan sebagai pedoman pembelajaran servis bawah. Hanya sedikit revisi mengenai instrument sikap yang kalimatnya agara dipermudah sehingga dapat dipahami siswa dengan baik. 3. Tes Pengetahuan

Dalam kaitan pengetahuan dalam penelitinaini ialah bagaimana siswa mengetahi berbagai macam gerkan teknik dasar servis bawah permianan bola voli. Sesuai dengan hasil presentase penelilaian tes pengetahuan servis bawah didapatkan 3 siswa atau $12,5 \%$ berada pada kategori sangat baik, 16 siswa atau $66,67 \%$ berada pada kategori baik dan 5 siswa atau $20,83 \%$ berada pada kategori cukup, dari hasil tes pengetahuan didapatkan $79,17 \%$ lulus KBM. Dengan demikian pengembangan model teknik dasar servis bawah permianan bola voli dapat dinyatakan layak.
Hasil belajar akumilasi dari penilaian 3 ranah adalah keterampilan didapatkan 91,67\%, ranah sikap didapatkan $95,83 \%$, dan ranah pengetahuan $79,17 \%$ maka jika dirata-ratakan didapatkan hasil $88,89 \%$ berada siswa berada pada kategori sangat baik.

\subsubsection{Tes kelas 7.5}

Uji efektifitas dilakukan pada kelas 7.5 dengan melihat hasil pembelajaran pada tiga ranah sebagai berikut:

\section{Tes Keterampilan}

Instrumen yang digunakan untuk melihat kualitas pembelajaran serta proses dalam melakukan gerakan keterampilan servis bawah permainan bola voli. tes keterampilan ini menggunakan observasi. Hasil presentase penilaian tes keterampilan proses servis bawah yang dilakukan melalui observasi keterampilan gerak siswa di didapatkan 8 siswa atau $33,34 \%$ berada pada kategori sangat baik, 16 siswa atau $66,67 \%$ maka siswa yang dinyataka lulus KBM adalah 100 dan berada pada kategori baik. Sesuai denga hasil penghitungan tersebut bahwa keterampilan siswa dapat meingkat dengan menggunakan model pengembangan servis bawah permainan bola voli tersebut dan dapat dinyatakan layak digunakan seabagai pedoman pembelajaran.

2. Tes sikap

Hasil presentase penelilaian observasi sikap servis bawah didapatkan 6 siswa atau $25 \%$ berada pada kategori sangat baik, 15 siswa atau $62,5 \%$ berada pada kategori baik dan 3 siswa atau $12,5 \%$ berada pada kategori cukup, dari hasil observasi tersebut didapatkan $87,5 \%$ siswa lulus KBM serta berada pada kategori sangat baik dan baik.

3. Tes Pengetahuan

Hasil presentase penelilaian tes pengetahuan servis bawah didapatkan 3 siswa atau $12,5 \%$ berada pada kategori sangat baik, 18 siswa atau $75 \%$ berada pada kategori baik dan 3 siswa atau $12,5 \%$ berada pada kategori cukup, dari hasil tes pengetahuan yaitu $87,5 \%$ siswa lulus KBM dan berada pada kategori baik.

Hasil belajar yang didapatkan siswa dari 3 ranah adalah $100 \%$ ranah keterampilan, $87,5 \%$ ranah sikap, dan $87,5 \%$ ranah pengetahuan dan dirata-ratakan maka didapatkan $91,67 \%$ berada siswa berada pada kategori sanagt baik.

\subsubsection{Tes Kelas 7.8}

Uji efektifitas dilakukan pada kelas 7.8 dengan melihat hasil pembelajaran pada tiga ranahsebagai berikut:

\section{Tes Keterampilan}

Pemain bola voli dapat dikatakan terampil jika dapat menguasai dan melakukan berbagai unsur gerakan dalam bola voli dengan baik, cermat, serta efektif dan efisien (Muslimin, 2018). Berdasarkan teori tersebut maka perlu adanya tes keterampilan sebagai 
salah satu bentuk tolak ukur siswa mampu melakukan servis dengan efektik dan efesien. Instrumen yang digunakan untuk melihat kualitas pembelajaran serta proses dalam melakukan gerakan keterampilan servis bawah permainan bola voli. tes keterampilan ini menggunakan observasi. Hasil presentase penilaian tes keterampilan proses servis bawah yang dilakukan melalui observasi keterampilan gerak siswa di didapatkan 5 siswa atau $20,83 \%$ berada pada kategori sangat baik, 19 siswa atau 79,17\% berada pada kategori baik. Hasil tes keterampilan yang didapatkan $100 \%$ siswa lulus KBM dan berada pada kategori baik.

2. Tes Sikap

Hasil presentase penelilaian observasi sikap servis bawah didapatkan 6 siswa atau $25 \%$ berada pada kategori sangat baik, 15 siswa atau $62,5 \%$ berada pada kategori baik dan 3 siswa atau $12,5 \%$ berada pada kategori cukup, dari hasil observasi didapatkan $87,5 \%$ siswa lulus KBM dan berada pada kategori sangat baik dan baik.

3. Tes Pengetahuan

Hasil presentase penelilaian tes pengetahuan servis bawah didapatkan 4 siswa atau $16,67 \%$ berada pada kategori sangat baik, 17 siswa atau $70,83 \%$ berada pada kategori baik dan 3 siswa atau $12,5 \%$ berada pada kategori cukup, dari hasil tes pengetahuan didapat $87,5 \%$ siswa lulus KBM dan berada pada kategori baik.

Hasil belajar siswa diakumulasikan dari 3 ranah yakni keterampilan $100 \%$, sikap $87,5 \%$, dan pengetahuan $87,5 \%$ maka rata-rata hasil belajar siswa didapatkan 91,67\% siswa berada pada kategori sangat baik.

\subsubsection{Hasil Dari Ujicoba Skala Besar}

Hasil dari ujicoba skala besar yang dilakukan pada 72 responden yang tersebar pada 3 kelas yang terdiri dari kelas 7,1 kelas 7,5, dan kelas 7,8 di dapatkan rata-rata $90,74 \%$ siswa dinyatakan lulus KBM. Hal ini dapat menyatakan bahwa model pembelajaran servis bawah dalam permainan bola voli Layak digunakan dalam pembelajaran.

\section{KESIMPULAN}

Pengembangan model pembelajaran servis bawah dilakukan pada SMP N 1 Palembang tahapan penelitian adalah analisis kebutuhan, pembeuatan draf produk, validasi ahli, ujicoba skala kecil, revisi, ujicoba skala besar serta ujiefektifitas produk. Hasil penelitian ini pada validasi ahli tahap 2 di dapatkan penilaian sebesar $80 \%$ dari ahli PJOK dan $81,67 \%$ dari ahli permainan bola voli maka produk dikatakatan "Layak". Ujicoba skala besar dilakukan pada 3 kelas dengan jumlah responden sebanyak 72 siswa didapatkan hasil yaitu, 90,74\% siswa berada pada kategori baik, sehingga produk ini dinyatakan "layak". Temuan pada penelitian ini adalah dihasilkannya model pembelajaran servis bawah permainan bola voli yang digunakan siswa SMP kelas VII berupa buku panduan. Implementasi dari penelitian ini adalah produk ini diharapkan dapat digunakan oleh guru Pendidikan Jasmani, Olahraga, dan Kesehatan sebagai bahan mengajar servis bawah permainan bola voli.

\section{SARAN}

Penelitian ini diharapkan dapat berguna bagi perkembangan dunia pendidikan dan olahraga. Dengan dikembangkannya model pembelajaran servis bawah permainan bola ini dapat menambah variasi guru SMP dalam model pembelajaran servis bawah. Hasil dari penelitain ini adalah buku panduan yang tentunya masih banyak kurangnya sehingga dibutuhkan masukan guna memperbaiki produk ini. Model pembelajaran ini diharapkan dapat dijadikan rujukan bagi peneliti selanjutnya untuk mengembangan model pembelajaran servis bawah permainan bola voli.

\section{DAFTAR PUSTAKA}

Aditama, Z. dan Hidayat, T. (2014). Penerapan Model pembelajaran STAD Terhadap Hasil Belajar Service Bawah Bolavoli. Jurnal Pendidikan Jasmani, Vol 2 (1), 41-44.

Agus Suprijono. 2010. Cooperative Learning. Yogyakarta. Pustaka Media.

Alif, E., Heny, S., \& Cahyo, Y. 2012. Modifikasi Model Pembelajaran Bola Voli melalui permainan Bola Voli Mini Berlapis. Journal of Physical Education, Sport, Healt and Recreation, (3) 185 189.

Husdarta, H.J.S. 2013. Manajemen Pendidikan Jasamani. Jakarta: Alfabeta.

Muslimin. 2018. Pengembangan Perangkat Tes dan Pengukuran Passing Bola Voli Berbasis Komputer. Jurnal Sosioteknologi, 17(2), 297-304.

Parisi, F., Raiola, G.2014.Video analysis in youth volleyball team, Journal of Human Sport and Exercise, 9, pp. S584-S587.

Rahayu, Ega Trisna. 2013. Strategi Pembelajaran Pendidikan Jasmani. Bandung: Alfabeta.

Sugiyono. 2013. Metode Penelitian Pendidikan (Pendekatan Kuantitatif, Kualitatif, dan $R \& D)$.Bandung: Alfabeta.

Syaiful Sagala. 2010. Konsep dan makna pembelajaran. Bandung: Alfabeta.

M.E. Winarno, dkk. 2018. Teknik dasar Bermain BolaVoli. Malang: Universitas Negeri Malang

Zhanneta Kozina, dkk. 2018. The influence of a special technique for developing coordination abilities on the level of technical preparedness and development of psycho-physiological functions of oung volleyball players 14-16 years of age. Journal of Physical Education and Sport (JPES), 18(3), Art 214, pp. $1445-1454$ 


\section{UCAPAN TERIMA KASIH}

Terimah kasih kepada Rektor Universitas Sriwijaya yang telah memberikan dana hibah penelitian unggulan kompetitif sehngga penelitian ini dapat terlaksana.

Terima kasih kepada validator, serta anggota penelitian sehingga penelitian ini dapat terselesaikan. 